University of Nebraska - Lincoln

DigitalCommons@University of Nebraska - Lincoln

\title{
Herbivory alters resource allocation and compensation in the invasive tree Melaleuca quinquenervia
}

\author{
P. D. Pratt \\ USDA-ARS
}

M. B. Rayamajhi

USDA-ARS

T. K. Van

USDA-ARS

T. D. Center

USDA-ARS

P. W. Tipping

USDA-ARS

Follow this and additional works at: https://digitalcommons.unl.edu/usdaarsfacpub

Part of the Agricultural Science Commons

Pratt, P. D.; Rayamajhi, M. B.; Van, T. K.; Center, T. D.; and Tipping, P. W., "Herbivory alters resource allocation and compensation in the invasive tree Melaleuca quinquenervia" (2005). Publications from USDA-ARS / UNL Faculty. 452.

https://digitalcommons.unl.edu/usdaarsfacpub/452

This Article is brought to you for free and open access by the U.S. Department of Agriculture: Agricultural Research Service, Lincoln, Nebraska at DigitalCommons@University of Nebraska - Lincoln. It has been accepted for inclusion in Publications from USDA-ARS / UNL Faculty by an authorized administrator of DigitalCommons@University of Nebraska - Lincoln. 


\title{
Herbivory alters resource allocation and compensation in the invasive tree Melaleuca quinquenervia
}

\author{
P. D. PRATT, M. B. RAYAMAJHi, T. K. VAN, T. D. CENTER and \\ P. W. TIPPING USDA/ARS, Invasive Plant Research Laboratory, Fort Lauderdale, Florida, U.S.A.
}

\begin{abstract}
Plants may compensate for the effects of herbivory, especially under favourable growing conditions, limited competition, and minimal topdown regulation. These conditions characterise many disturbed wetlands dominated by introduced plants, implying that exotic, invasive weeds in these systems should exhibit strong compensatory responses.

2. The Australian native Melaleuca quinquenervia is highly invasive in the Florida Everglades, U.S.A., where it experiences limited competition or herbivory from native species, making it a likely candidate for compensation. The introduced biological control agent Oxyops vitiosa feeds exclusively on the seasonal flushes of developing foliage at branch apices, which represents $\approx 15 \%$ of the total foliar biomass.

3. The hypothesis that $M$. quinquenervia compensates for folivory by $O$. vitiosa was tested in a series of field-based experiments. Trees experiencing folivory over four consecutive years maintained similar levels of foliar biomass after attack yet possessed twice the number of leaf-bearing terminal stems as undamaged trees. The biomass of these stems was similar among attacked and unattacked trees, indicating that herbivore-damaged trees produce greater quantities of smaller terminal branches. However, undamaged trees were 36 times more likely to reproduce than herbivore-damaged trees.

4. In a separate herbivore exclusion study, a single bout of herbivory on previously undamaged $M$. quinquenervia trees caused an $80 \%$ reduction in reproductive structures the following season. Herbivore-damaged trees also possessed $54 \%$ fewer fruits than undamaged trees. An increase in the herbivory frequency (two bouts per year) or magnitude (100\% simulated herbivory) did not result in a further reduction in fitness.

5. It has been concluded that $M$. quinquenervia partially compensates for herbivory by producing new stems and replacing foliage, but this compensation results in a substantial reduction in reproduction.
\end{abstract}

Key words. Biological control, defoliation, invasive species, Myrtaceae, plant architecture, plant-insect interactions, reproduction, tolerance, top-down regulation.

\section{Introduction}

Herbivory is a fundamental component of most terrestrial communities yet the influence of herbivory on performance and population regulation varies widely among plant taxa.

Correspondence: Paul D. Pratt, USDA/ARS, Invasive Plant Research Laboratory, 3205 College Avenue, Fort Lauderdale, FL 33314, U.S.A. E-mail: prattp@saa.ars.usda.gov
These differences in responses to herbivore attack may relate to the plant's compensatory abilities (e.g. maintenance of equivalent biomass or fitness) subsequent to feeding damage. Injury-induced compensation is commonly categorised into three discrete levels including under-, fully (nullifying), or over-compensation for the effects of herbivory (Belsky, 1986). However, a growing body of literature suggests that herbivore-mediated responses within a single species may range along a continuum from 
under- to over-compensation depending on environmental factors experienced by the plant. Maschinski and Whitham (1989), for instance, determined that growth of Ipomopsis arizonica (Greene) Wherry varied from fully to undercompensation according to the level of interspecific competition and timing of attack. In addition to these factors, Belsky $(1986,1987)$ predicts that over-compensation has the highest probability of occurrence when plants are growing in moderately grazed aquatic systems where nutrients are abundant and interspecific competition is limited. These conditions are characteristic of many wetlands dominated by introduced plants, suggesting that exotic, invasive weeds in these systems should exhibit strong compensatory responses.

Plasticity of plant fitness in responses to herbivory is of particular interest when considering that exotic arthropods are intentionally introduced beyond their native range as a means of re-establishing top-down population regulation of invasive plants. A key underlying assumption of classical weed biological control is that the reunion of natural enemies with their coevolved hosts will suppress plant performance and result in the replacement of the invasive species with more desirable vegetation (McEvoy et al., 1993). Although this approach has provided exceptional suppression of several problematic weeds, some introduced herbivores appear to have little or no influence on the fitness of their hosts (Julien, 1989; Harris, 1993; McFadyen, 1998). A variety of herbivore-centric hypotheses have been proposed to explain these less than satisfactory results. Harris (1973) suggested, for example, that biological control agent selection protocols favour obtaining safe, rather than highly damaging, herbivores. In addition, environmental conditions in the adventive range may be unsuitable for the herbivore (Harris, 1988, 1993), or may produce plants of poor nutritional quality (Thomas \& Room, 1985; Wheeler $\&$ Center, 1996). The influence of biotic resistance, i.e. the acquisition of higher trophic levels in the herbivore's adventive range, is a commonly cited factor that can limit topdown population regulation (Goeden \& Louda, 1976; Pratt et al., 2003a). Inaccurate matching of herbivore and hostplant biotypes can also reduce herbivore impacts (Dray, 2003; Dray \& Center, 1996). However, the compensatory abilities of invasive plants to mitigate the impacts of introduced herbivores have rarely been investigated.

Melaleuca quinquenervia (Cav.) S.T. Blake, a target of weed biological control, possesses characteristics consistent with plant systems that are predicted to compensate for the effects of herbivory. This invasive plant is a large $(>20 \mathrm{~m})$ Australian tree that was introduced into the wetlands of Florida, U.S.A. in the late 1880s (Dray, 2003). Melaleuca quinquenervia is competitively superior to most, if not all, native vegetation occurring in the historically forested and sawgrass-dominated wetlands that characterise the Florida Everglades (Turner et al., 1998). In the absence of its coevolved herbivores, pathogens and parasites, $M$. quinquenervia experiences limited top-down population regulation from a small assemblage of generalist species (Rayachhetry et al., 2001; Costello et al., 2003). Like other long-lived perennials, M. quinquenervia accumulates root-bound starch reserves that may be mobilised to replace damaged tissue, thereby buffering trees from the effects of consumers (Maron \& Vila, 2001).

To limit invasion and provide a biologically based approach to the control of the invasive tree, explorations for natural enemies of $M$. quinquenervia were conducted in eastern Australia (Burrows \& Balciunas, 1999). The curculionid weevil, Oxyops vitiosa Pascoe, was the first species selected for quarantine-based host specificity testing (Purcell \& Balciunas, 1994) and, once deemed sufficiently host specific, this species was released in South Florida in 1997, where it is considered established throughout the range of M. quinquenervia (Center et al., 2000; Pratt et al., 2003b). Adult weevils feed indiscriminately and superficially on M. quinquenervia foliage while larvae are specialised flush feeders, consuming newly developed, expanding leaves that are ephemerally produced in seasonal flushes at branch apices (Purcell \& Balciunas, 1994; Pratt et al., 2004). When fully exploiting the available resource, herbivory results in removal of $\approx 15 \%$ of the foliar biomass (Pratt et al., 2004).

When considering the invasive plant's favourable growing conditions in Florida, its competitive superiority, and the type as well as frequency of damage inflicted by $O$. vitiosa, it was questioned if $M$. quinquenervia compensates for herbivory. As the primary goal for introducing $O$. vitiosa was to indirectly reduce the invasive tree's reproductive capacity, in this study plant compensation is viewed in terms of alterations in resource allocation and reproductive performance relative to that in the absence of herbivory (Bazzaz \& Ackerly, 1992; Strauss \& Murch, 2004). The hypothesis that $M$. quinquenervia compensates for indirect effects of folivory by $O$. vitiosa was tested in terms of growth, tissue production, and reproductive performance (compensation hypothesis). This hypothesis was tested by (1) quantifying the impacts of herbivory on plant partitioned biomass, (2) assessing the incidence and intensity of foliar damage as a predictor of reproduction, and (3) evaluating the interactions among herbivory frequency, floral intensity, fruit production, and seed quality.

\section{Materials and methods}

\section{Study species}

In its native range, M. quinquenervia occurs along Australia's north-eastern coast from Sydney in New South Wales to the tip of Cape York Peninsula in northern Queensland, in New Guinea, and in New Caledonia (Boland et al., 1987). Multiple introductions of M. quinquenervia seeds were made on both the eastern and western coasts of South Florida, resulting in highest concentrations of the weed along the coastal areas south of the northern rim of Lake Okeechobee. In Florida, synchronised flowering events occur during winter (dry season) although some $M$. quinquenervia trees reproduce at unpredictable intervals (Meskimen, 1962). Inflorescences are indeterminate, $2-5 \mathrm{~cm}$ 
long, and arranged in bottlebrush-like spikes (Holliday, 1989). Persistent capsular fruits arise from flowers and are arranged in a series of clusters, which may remain attached to the trunks, branches, or twigs for several years (Meskimen, 1962). For the purposes of this study, the most distally located capsule clusters are referred to as primary clusters, with subsequent proximal clusters described as secondary, tertiary, etc. A flower spike in its adventive range can produce $30-70$ sessile capsules and up to seven consecutive capsule clusters (which may or may not be separated by series of leaves) have been recorded from M. quinquenervia branches (Rayachhetry et al., 1998). These serotinous capsules release seeds when vascular connections are disrupted by increased bark thickness or stresses such as fire, frost, mechanical damage, herbicide treatments, or self-pruning of branches (Woodall, 1982). Capsules contain 200-350 seeds each (Meskimen, 1962), yet only $9 \%$ of these seeds are viable (Rayachhetry et al., 1998). The canopy of a mature tree $(38 \mathrm{~cm}$ diameter at breast height and $12 \mathrm{~m}$ tall) may hold up to $1.4 \mathrm{~kg}$ of seeds (about 56 million seeds, Rayamajhi et al., 2002). Because of the massive seed release from mother trees, dense, monospecific $M$. quinquenervia stands are common (Hofstetter, 1991; Van et al., 2000).

Oxyops vitiosa is a curculionid weevil that is native to eastern Australia and feeds exclusively on species in the Melaleuca leucadendra species complex, of which Melaleuca quinquenervia is the southern-most member (Balciunas et al., 1994). In its introduced range, oviposition occurs mainly during daylight hours from October to March (Center et al., 2000). Eggs are deposited on the surface of expanding foliar buds, young leaves, or elongating stems. A hardened coating of frass and glandular material covers individual eggs (Purcell \& Balciunas, 1994). Larvae are ectophages, feeding on one side of the leaf through to the cuticle on the opposite, producing a window-like feeding scar. After the completion of five instars, larvae drop to the forest floor and pupate in the soil. In the absence of suitable phenological stages of its host, larvae are uncommon during summer months (April to September) unless damageinduced regrowth is present (Center et al., 2000). Adult weevils can live in excess of one year and females produce $\approx 350$ eggs during their lifetime (Wheeler, 2003).

\section{Influence of herbivory on flower incidence}

An experiment was designed to test the influence of herbivory by $O$. vitios $a$ on the incidence of $M$. quinquenervia inflorescence and fruit production at three sites in South Florida. Sites were selected randomly from among nine locations where the herbivores were initially established and correspond with release sites 1, 12, and 13 in Center et al. (2000). Regionally, the selected sites represent a range in the plant's geographic distribution and invaded habitat types (Table 1). To assess more accurately the variation in reproductive performance among trees not attacked by the herbivore (Underwood, 1992, 1994), three additional stands in close proximity to each study site $(<3 \mathrm{~km})$, yet occurring outside the limited geographic range of the herbivore, were selected to serve as 'controls' for statistical comparisons ( 3 study sites $\times 3$ control sites $=9$ total control sites). Other than the absence of $O$. vitiosa, control sites were selected without apparent bias and possessed similar hydrology, soil types, size-class distribution, and occurred in the same habitats as the corresponding stands experiencing herbivory (Table 1).

The incidence of inflorescence and fruit production was assessed at all sites during spring (February to April) 2000 by randomly selecting a transect radiating through each stand. Three individuals walked abreast along each transect and independently recorded the diameter at breast height (1.3 $\mathrm{m}$ above ground surface $=$ d.b.h. $),$ O . vitiosa feeding damage, the presence of old capsule clusters, new clusters and inflorescences for each tree occurring within $1 \mathrm{~m}$ on each side of the transect. Trees $>6 \mathrm{~cm}$ d.b.h. were not included due to the difficulty of accurately assessing the canopy parameters. Sampling continued until $\approx 150$ trees were evaluated per stand. Feeding damage was assessed on a five-point scale based on a visual estimation of percentage of the suitable foliage destroyed by weevil feeding: 0 , no damage; $1,<25 \%$ destroyed; 2, 26-50\%; 3, 51-75\%; $4,76-100 \%$ destroyed. Recently developed capsules remain green for 2-4 months after flowering and are easily distinguished from the previous season's grey-coloured capsules. Incidence data for inflorescence and newly developed capsules were pooled prior to analysis.

The influence of herbivory on reproductive incidence was analysed with the logistic regression model,

Table 1. Study sites used for quantifying the influence of herbivory by Oxyops vitiosa on resource allocation and compensation in the invasive tree Melaleuca quinquenervia.

\begin{tabular}{llllll}
\hline & Study site & GPS coordinates* & Hydroperiod $\dagger$ & Soil type & Habitat type \\
\hline Holiday Park & $26.0537 \mathrm{~N}$ & $-80.4409 \mathrm{~W}$ & Short & Histisolsł & Wet prairie \\
Everglades National Park & $25.6925 \mathrm{~N}$ & $-80.50638 \mathrm{~W}$ & Moderate & Histisolsł & Swale \\
Estero & $26.4255 \mathrm{~N}$ & $-81.81033 \mathrm{~W}$ & Short & Entisols§ & Mesic \\
& & & & flatwoods \\
\hline
\end{tabular}

*Global positioning system in decimal degrees.

†Short, inundated <6 months; moderate, 6-9 months (Ewel, 1990).

\#Lauderhill series: Siliceous, hyperthermic Lithic Psammaquents.

§Hallandale series: Euic, hyperthermic Lithic Medisprists. 


$$
\begin{aligned}
\operatorname{logit}(\text { flower })= & \beta_{0}+\beta_{1} \text { dbh }+\beta_{2} \text { capsule } \\
& +\beta_{3} \text { herbivory, }
\end{aligned}
$$

which accounts for variation in plant size $(d b h)$, the presence of pre-existing capsule clusters, and incidence of herbivory (SAS Institute, 1990). To test the assumption of linearity, the preceding model was embedded in a larger equation that included quadratic terms to examine departure from linearity (Ramsey \& Schafer, 2002). Stepwise reduction of all full models was used, removing the least significant $(P>0.05)$ quadratic and highest order interactions first (Ramsey \& Schafer, 2002). Damage and herbivory variables were not considered independent and therefore analysed separately. Orthogonal contrasts were used to differentiate among damage levels.

In addition to comparing the binomial response of reproductive performance, flowering probability was compared among herbivory treatments by pooling data from all damaged and non-damaged sites, respectively, calculating the flowering frequency for each d.b.h. increment measured and regressing the frequency on the d.b.h. range. To meet assumptions of normality and homogeneity of variances implicit in the parametric analysis, the arcsine transformation was applied to frequency data prior to analysis. Comparison of regression lines was performed using analysis of covariance (ANCOVA), with tree diameter as the covariate (SAS Institute, 1990).

\section{Influence of cumulative herbivory on above-ground resource allocation}

Trees near the epicentre of each release site had been routinely attacked during the 4 years after the introduction of $O$. vitiosa, resulting in repeated defoliation of the terminal foliage. Experimentally, costs of reallocating resources to the replacement of damaged tissue can be addressed through comparison of proportionate changes in plant biomass (Bazzaz \& Ackerly, 1992). To test if the replacement of damaged leaves draws on photosynthetic reserves that are normally partitioned to other sources, 20 trees that ranged from 1 to $6 \mathrm{~cm}$ d.b.h. were selected at each of the three herbivory stands and one randomly selected stand from among the three corresponding replicated control sites for each herbivory site (see above). Selection criteria included trees with a single trunk (non-bifurcated) and growing in an open environment. Plant biomass allocation was quantified in June 2000 by cutting each tree at the soil level, measuring tree height, live crown volume, and separating the main trunk and branch components: branches, twigs, leaves, and capsule clusters. In addition, the number of capsule clusters, cluster length, capsules per cluster, number of branches, and the number of buds per branch were noted. Each component for all trees was weighed both fresh and dry (oven dried at $70^{\circ} \mathrm{C}$ for $\approx 21$ days). Differences in plant partitioned biomass among treatments were compared with ANCOVA, with tree diameter as the covariate (SAS Institute, 1990).

\section{Within-season influence of herbivory reproductive allocation}

In the previous studies the cumulative $(\approx 4$ year $)$ impacts of herbivory on a range of $M$. quinquenervia tree sizes (d.b.h.) was evaluated. To quantify the within-season impacts of herbivory on reproductive performance, 60 evenly sized trees growing along a road cut near Weston, Broward Co., Florida $\left(26.14006^{\circ} \mathrm{N},-80.34545^{\circ} \mathrm{W}\right)$ were selected. Trees were growing in typical reclaimed 'glades' soil characterised by high organic matter and moderate hydroperiods. Only trees occurring along the western exposure of the road were used in the study. In general, selected trees were of similar d.b.h. $\left(\bar{x}=2.91 \mathrm{~cm} ; F_{5,59}=0.74\right.$; $P=0.5943), \quad$ height $\quad\left(\bar{x}=4.60 \mathrm{~m} ; \quad F_{5,59}=0.94 ;\right.$ $P=0.4616)$, experienced an average of 3.83 ( $\mathrm{SE} \pm 0.170$; $F_{5,59}=0.52 ; P=0.7572$ ) flowering events prior to the experiment and possessed similar capsule cluster densities per tree $\left(\bar{x}=54.58 ; F_{5,59}=0.49 ; P=0.7801\right)$.

By 15 February 2000 all trees had produced a flush of newly developed, expanding leaves (susceptible phenological stage) and 10 trees were randomly assigned to each of six treatments. The first treatment consisted of placing a sleeve cage constructed of a light weight, tightly woven grey nylon mesh screen over the canopy of each tree on 17 February. The following day 200 third and fourth $O$. vitiosa larval instars were released into each of the 10 cages. Two weeks later, larvae had consumed much of the susceptible foliage and dropped to the bottom of the cage to pupate. Cages were removed on 4 March while ensuring that all pupae and larvae were extracted. The second treatment was exactly like the first except larvae were not introduced into the cages so as to provide caged controls. The third treatment was similar to the first except that each sleeve cage was replaced on 27 April 2000 and an additional 200 larvae were reintroduced into the cages, as before, to exploit a second flush of growth that arose in response to the initial defoliation. Larvae, pupae, and cages were removed 2 weeks later. The fourth treatment was exactly like the third except larvae were not introduced into the sleeve cages. The fifth treatment was never caged; however, all the leaves were mechanically removed at their petioles on 18 February. The remaining 10 trees served as uncaged controls.

Trees were monitored monthly after treatment implementation until 5 July 2000, when the first flowers were initiated and biweekly sampling occurred thereafter. Sampling consisted of recording the number of new inflorescences produced per tree, the length of each inflorescence and the number of florets per inflorescence. Inflorescence length was measured from the bract scar at the base of the flower to the base of the most distal floret. Inflorescences can persist $>2$ weeks so new inflorescences were tagged at each sampling interval. The numbers of dormant, expanding, and epicormic buds were also assessed using a fivepoint scale: 1, 1-5 buds per tree; 2, 6-10 buds; 3, 11-15 buds; 4, 16-20 buds; and 5, >21 buds. Epicormic buds were differentiated from normally expanding buds by their location on the tree, with epicormic buds arising from woody branches in the lower regions of the canopy as a result of loss of apical dominance at the branch tip. Flowering 
ceased after 17 January 2001 and trees were monitored thereafter at monthly intervals until 31 July.

Analysis of variance was used to test for differences among cage and uncaged controls. Pre-planned orthogonal contrasts were used to compare the cumulative number of inflorescences per tree, capsules per cluster, vegetative bud stages, and the number of new buds among herbivory and corresponding control treatments (SAS Institute, 1990). The Kruskal-Wallis test was used to compare the frequency of adventitious regrowth among treatments, followed by Fisher's Least Significant Difference test on ranked data.

\section{The influence of herbivory on seed quantity and viability}

In the previous experiments changes in flower, fruit, and plant growth in response to herbivory was quantified. However, evidence of alterations in resource allocation as a result of herbivory may also be manifest in the quantity and quality of seeds. Using the 60 trees from the previous study, a maximum of five randomly selected clusters that arose after administration of treatments were collected. For those trees that produced $\leq 5$ flowers, all capsule clusters were harvested. Clusters were excised from branches on 1 October 2001, placed into individual marked polyethylene bags and transported to the laboratory. The number of capsules per cluster was recorded, after which each capsule was removed and individually placed in a separate sealed glass vial. Capsules began to open 2 days later and by 9 October all capsules had released seeds.

Seed quantity and viability was assessed by randomly selecting 15 capsules per treatment from among those clusters collected. This was carried out by evenly spreading all seeds per capsule into individual sterile Petri dishes (5-cm diameter; Microfiltrations Systems, Dublin, CA), each containing a sterile filter paper. Filter papers were soaked with $2 \mathrm{ml}$ of $0.5 \%$ 2,3,5triphenol tetrazolium chloride (TTC; Sigma Chemical Co., St Louis, MO), leaving a film of liquid on the surface. The dishes were closed and sealed with parafilm and placed in a dark cabinet drawer at $24{ }^{\circ} \mathrm{C}( \pm 2)$. Filled (embryonic) seeds appeared dark and non-transparent when viewed with back lighting. However, seeds with living, respiring embryos stained red after soaking for 7 days in TTC and were considered viable while non-viable seeds remained white to light pink (Grabe, 1970; Rayachhetry et al., 1998). Seed viability was calculated by dividing red stained seeds by the total seeds per capsule. Treatment level effects were analysed with ANOVA and means were compared with a Tukey HSD test. Caution should be used when making inferences concerning seed viability among treatments as very few capsule clusters were developed among damaged trees.

To test the assumption that seed viability does not vary among capsules within a cluster, five clusters that possessed a full, or nearly full, complement of capsules were selected. These clusters originated from trees assigned 'control' treatments due to the lack of complete clusters from the herbivory and mechanically damaged trees. For these clusters, the numbers of seeds per capsule were counted and seed viability was quantified as described earlier.

\section{Results}

Influence of herbivory on flower incidence

Trees experiencing folivory over four consecutive years demonstrated a lower incidence of reproduction than undamaged trees $\left(\chi_{1}^{2}=258.59, P<0.001\right)$. The fit of a reduced logistic regression model to these data gives:

$$
\begin{aligned}
\operatorname{logit}(\text { flower })= & -9.5136+0.3855 \mathrm{dbh} \\
& +2.2856 \text { oldcapsules } \\
& +3.5839 \text { herbivory. }
\end{aligned}
$$

The odds that undamaged M. quinquenervia trees would reproduce were 36 times greater than herbivore-damaged trees [95\% Wald confidence interval (CI): 23.269-55.744]. Not surprisingly, flowering incidence across all sites increased with tree diameter $\left(\chi_{1}^{2}=62.37, P<0.001\right)$ independent of herbivory $\left(\chi^{2}{ }_{1}=0.42, P<0.517\right)$. From these data it was estimated that the odds of reproducing increase by a factor of 1.47 for each centimetre in d.b.h. (95\% CI for multiplicative odds factor is 1.34-1.62). Flowering incidence was also influenced by the presence of serotinous capsule clusters, with those trees that have flowered in the past having a higher likelihood of flowering in the future $\left(\chi^{2}{ }_{1}=213.30\right.$, $P<0.001)$. Foliar damage also influenced reproductive performance $\left(\chi_{1}^{2}=250.05, P<0.001\right)$, with the higher damage levels 3 and 4 ( $\approx 51-100 \%$ defoliation) resulting in lower reproductive incidence as compared with the absence or minimal levels of damage (levels $0-1$ ), with level 2 being intermediate. The probability of flowering was significantly lower than undamaged trees across the entire range of tree sizes evaluated $\left(F_{1,98}=11.02, P=0.001\right.$; Fig. 1$)$.

\section{Influence of herbivory on above-ground resource allocation}

Herbivory did not influence the number of large structural branches, tree height or crown volume (Table 2). Similarly, there were no differences in leaf biomass among damaged and undamaged trees $\left(F_{1,86}=0.324, P=0.571\right)$. However, the number of small (terminal) twigs and foliar buds occurring on twigs were significantly greater for trees that experienced herbivory (Table 2). Fewer newly developed (green) and primary capsule clusters occurred on those trees that were attacked by $O$. vitiosa, although no difference in the number of capsule clusters in secondary and tertiary positions was observed. The mean length of newly developed stems was greater for those trees outside the geographic range of the herbivore (Table 2). Herbivory did not influence the length of capsule clusters but those clusters produced on damaged trees possessed fewer capsules than undamaged trees.

Herbivory by $O$. vitiosa resulted in the defoliation of $94.5 \%$ of the suitable, expanding foliage after the first herbivory event (measured 35 days after release), mechanical damage provided $100 \%$ defoliation of all leaves and control trees experienced no damage. Foliar damage, regardless of the source, induced vegetative bud 
Fig. 1. Observational assessment of flowering frequency among herbivore-damaged and undamaged trees across a range of tree sizes $(n=1874) ; 95 \%$ confidence intervals are shown.

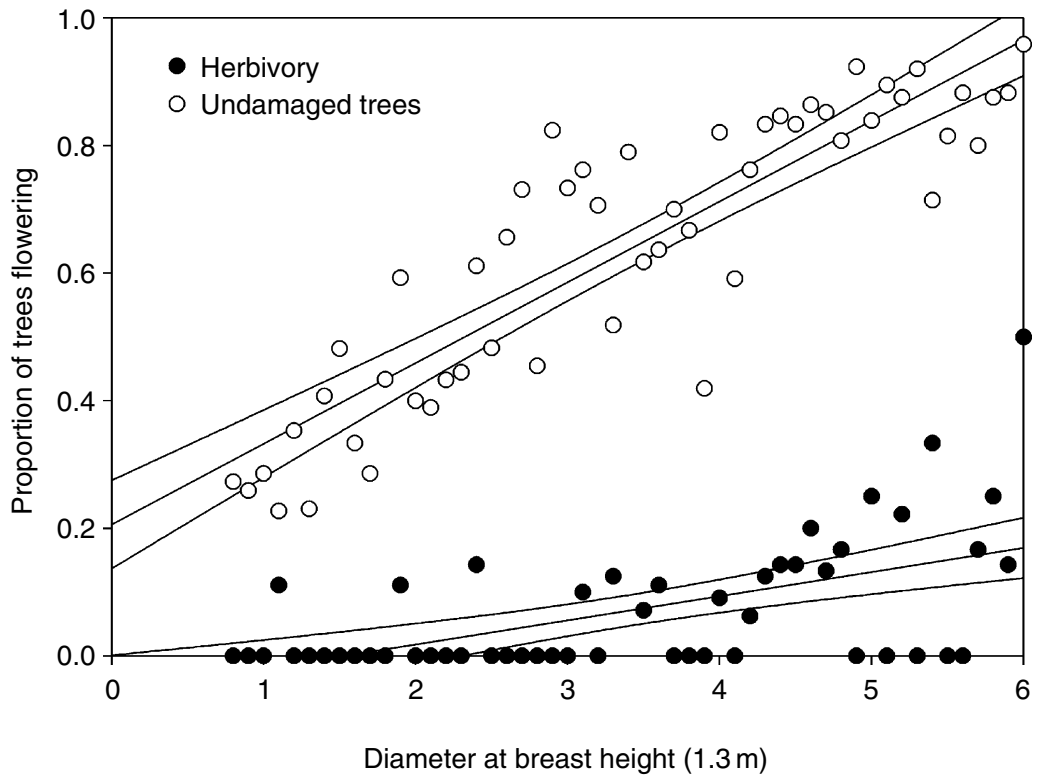

Within-season influence of herbivory on reproductive allocation

Caging trees had no significant effect on measured parameters $\left(F_{2,29}=2.34 P=0.1160\right)$. Foliar damage reduced the cumulative inflorescences produced per tree $\left(F_{3,52}=11.01, P<0.001\right.$; Fig. 2). There were no differences among herbivory frequency or damage type (Fig. 2). The number of flowers produced per inflorescence was $43.2( \pm 14.3)$ and did not differ among treatments $(P=0.310)$. The length of the few capsule clusters produced on damaged trees was not different from those produced on undamaged trees (pooled $\bar{x}=6.01 \mathrm{~cm} ; F_{5,23}=1.25$, $P=0.2643)$. Similarly, there was no difference in capsule abortion among treatments $\left(F_{3,97}=1.30, P<0.2781\right)$.

Table 2. The influence of folivory by Oxyops vitiosa on resource allocation of Melaleuca quinquenervia. Values represent average counts of plant parameters $\pm \mathrm{SE}$, unless otherwise noted.

\begin{tabular}{|c|c|c|c|c|}
\hline \multirow[b]{2}{*}{ Plant response } & \multicolumn{2}{|l|}{ Mean $( \pm \mathrm{SE})$} & \multirow[b]{2}{*}{$F$} & \multirow[b]{2}{*}{$P$-value } \\
\hline & Undamaged & Damaged & & \\
\hline Tree height $(\mathrm{m})$ & $3.99(0.20)$ & $4.21(0.20)$ & 0.237 & 0.628 \\
\hline Crown volume $\left(\mathrm{m}^{3}\right)$ & $2.31(0.23)$ & $2.40(0.25)$ & 0.127 & 0.722 \\
\hline Structural branches & $33.31(3.19)$ & $34.74(2.31)$ & 0.16 & 0.690 \\
\hline Terminal branches (apices) & $148.60(21.40)$ & $298.87(32.01)$ & 31.285 & $<0.001$ \\
\hline Vegetative buds & $79.08(9.82)$ & $115.13(15.53)$ & 6.97 & 0.010 \\
\hline \multicolumn{5}{|l|}{ Capsule clusters } \\
\hline New capsules & $31.18(6.95)$ & $2.61(2.46)$ & 16.749 & $<0.001$ \\
\hline Primary & $49.28(9.80)$ & $26.54(5.97)$ & 5.112 & 0.026 \\
\hline Secondary & $9.18(4.44)$ & $3.82(1.46)$ & 1.49 & 0.235 \\
\hline Tertiary & $2.96(2.07)$ & $0.13(0.08)$ & 1.949 & 0.166 \\
\hline Cluster length (cm) & $5.06(0.19)$ & $5.43(0.20)$ & 2.756 & 0.101 \\
\hline Capsules per cluster & $31.28(2.16)$ & $17.04(1.92)$ & 23.548 & 0.001 \\
\hline New stem length $(\mathrm{cm})$ & $21.88(2.12)$ & $9.43(1.39)$ & 25.208 & $<0.001$ \\
\hline
\end{tabular}




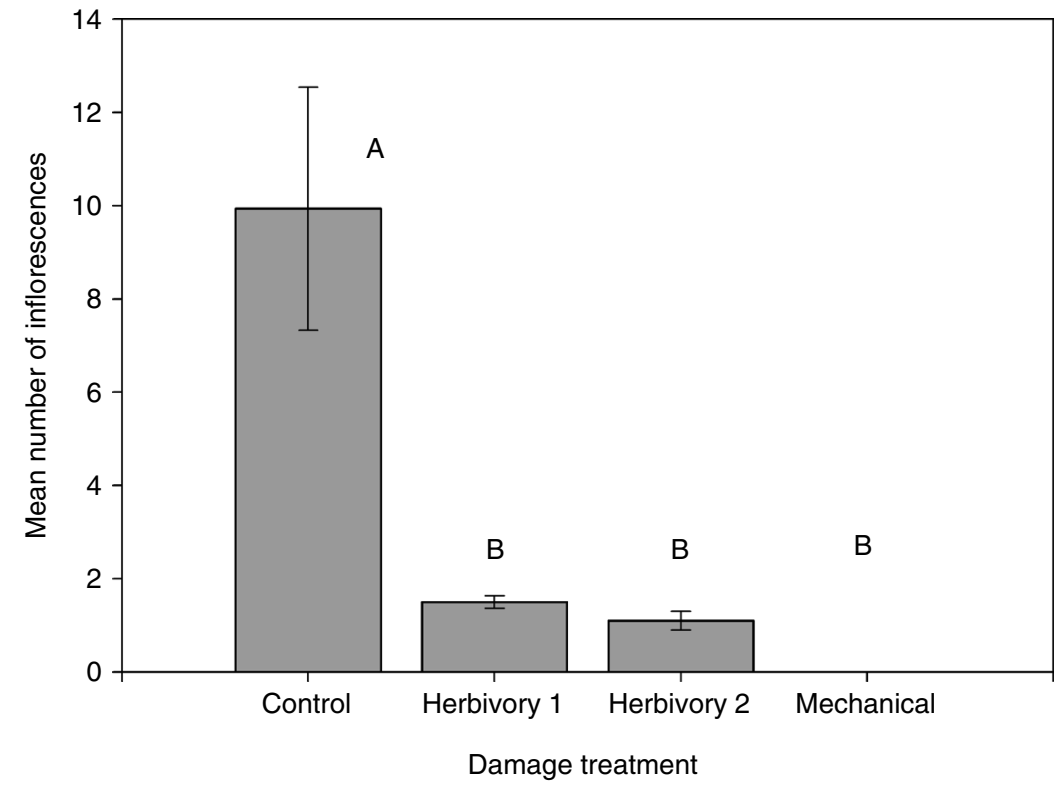

Fig. 2. Mean number of inflorescences ( $\pm 1 \mathrm{SE})$ produced by trees after experiencing no, one (Herbivory 1), or two (Herbivory 2) herbivory bouts or mechanical removal of all leaves. Letters indicate significant differences $(P<0.05)$ between means compared with preplanned orthogonal means comparisons.
Impacts of herbivory on seed quantity and viability

Capsule location within a cluster did not influence seed fill $\left(F_{1,206}=2.81, P=0.10\right)$ or viability $\left(F_{1,206}=2.24\right.$, $P=0.14)$. When pooling data within a cluster, the number of seeds produced per capsule was lower in mechanically damaged trees as compared with all other treatments (Table 3). In contrast, the per cent of viable seeds within capsules was greatest in mechanically damaged trees, lowest for undamaged trees and intermediate for trees attacked by O. vitiosa (Table 3). Similarly, those trees defoliated mechanically had significantly higher rates of seed fill as compared with undamaged trees, with a single herbivory event intermediate (Table 3 ).

\section{Discussion}

Few studies have examined the influence of herbivory on the hierarchy of resource allocation and compensation in woody perennials (Whitham \& Mopper, 1985; Doak,
1992). Herein, herbivory by $O$. vitiosa resulted in initial reduction of foliar biomass and disruption of apical dominance of $M$. quinquenervia branch meristems. This damage led to elongation of auxiliary buds and resulted in replacement of foliar biomass to pre-herbivory levels (Table 2). After a single bout of herbivory, for instance, $90 \%$ of the damaged branches produced regrowth from epicormic buds in contrast to $7 \%$ of undamaged branches. Consequently, herbivore-damaged $M$. quinquenervia trees possessed twice the number of leaf-bearing terminal stems as undamaged trees (Table 2). The biomass of these stems was similar among treatments, demonstrating that herbivore-damaged trees produce greater quantities of smaller terminal branches. From these data it is apparent that $M$. quinquenervia reallocates resources to production and maintenance of photosynthetic tissues to compensate for the impacts of herbivory. This finding is thus consistent with the hypothesis that highly competitive invasive plants can compensate for herbivory.

Despite the fact that $M$. quinquenervia was able to replace lost leaf tissue, herbivore-damaged plants had

Table 3. Seed production among Melaleuca quinquenervia trees experiencing no, one (Herbivory 1), or two (Herbivory 2) herbivory bouts or simulated (mechanical) removal of all leaves. Values represent averages of individual capsules \pm SE. Means followed by the same letter within rows are not significantly different at the $P<0.05$ level (Tukey's HSD).

\begin{tabular}{|c|c|c|c|c|c|c|c|c|}
\hline & \multicolumn{3}{|l|}{ Control } & \multirow[b]{2}{*}{ Herbivory 1} & \multirow[b]{2}{*}{ Herbivory 2} & \multirow[b]{2}{*}{ Mechanical } & \multirow[b]{2}{*}{$F$} & \multirow[b]{2}{*}{$P$} \\
\hline & Uncaged & Cage 1 & Cage 2 & & & & & \\
\hline Seed number & $227.92^{\mathrm{a}}$ & $212.42^{\mathrm{a}}$ & $204.46^{\mathrm{a}}$ & $221.23^{\mathrm{a}}$ & $202.31^{\mathrm{a}}$ & $158.63^{\mathrm{b}}$ & 2.94 & 0.0163 \\
\hline No. viable seed & 23.64 & 21.83 & 23.46 & 35.80 & 29.94 & 27.25 & 1.32 & 0.2625 \\
\hline No. non-viable & 23.80 & 24.33 & 19.85 & 27.93 & 18.45 & 31.63 & 1.56 & 0.1793 \\
\hline Embryonic & 47.44 & 46.17 & 43.31 & 63.73 & 38.38 & 58.88 & 1.26 & 0.2891 \\
\hline Per cent viable & $10.24^{\mathrm{bc}}$ & $9.22^{\mathrm{c}}$ & $10.45^{\mathrm{bc}}$ & $16.05^{\mathrm{ab}}$ & $15.31^{\mathrm{abc}}$ & $17.16^{\mathrm{a}}$ & 2.43 & 0.0405 \\
\hline Per cent embryonic & $20.35^{\mathrm{a}}$ & $20.55^{\mathrm{a}}$ & $19.92^{\mathrm{a}}$ & $29.34^{\mathrm{ab}}$ & $19.44^{\mathrm{a}}$ & $37.84^{\mathrm{b}}$ & 2.53 & 0.0337 \\
\hline
\end{tabular}


substantially lower reproduction than undamaged trees. Undamaged trees were 36 times more likely to reproduce than herbivore-damaged trees, and the number of seed capsules per cluster arising from the few flowers produced on damaged trees was $54 \%$ lower than undamaged trees. This reallocation of resources to maintenance of foliage resulted in a concomitant reduction in reproduction across the entire range of tree sizes studied (Fig. 1). These data demonstrate that production and maintenance of photosynthetic tissues by $M$. quinquenervia appears to be given greater priority over reproduction after attack by $O$. vitiosa. Thus $M$. quinquenervia partially compensates for herbivory by producing new stems and replacing foliage, but at a significant cost to reproduction. With sufficient levels of herbivory, the resulting loss in reproductive capacity should ultimately lead to declines in $M$. quinquenervia populations, despite shortterm replacement of damaged tissue.

To determine in greater detail how herbivory alters patterns of allocation to reproductive function, the number of inflorescences and capsules produced by $M$. quinquenervia was quantified as an estimate of resources allocated to reproduction. Browsed $M$. quinquenervia trees produced fewer flowers, capsule clusters, and capsules per cluster. However, this reproductive inhibition may be mitigated by increased seed viability within the few seed capsules that are produced. Does $M$. quinquenervia compensate for herbivory by increasing seed viability (Smith \& Bass, 1972)? These data demonstrate that natural herbivory levels and frequencies tested herein do not influence seed number, embryony or viability (Table 3). However, severe levels of simulated herbivory result in $27 \%$ fewer seeds but a greater percentage of embryonic and viable seeds per capsule (Table 3). This increase in seed quality may indicate that M. quinquenervia possesses a compensatory mechanism for mitigating intense grazing pressure. Increase in seed quality may, in contrast, be related more to a concentration of available resources to a reduced subset of seeds. These increases in seed quality are slight, representing a $2 \%$ increase in the number of viable seeds. The biological significance as well as the underlying mechanisms that influence increased embryony and viability among severely damaged trees remains uncertain.

One mechanism by which plants may compensate for herbivory is through the release of apical dominance and the associated increase in growth from non-apical meristems (Bazely \& Jefferies, 1989; Trumble et al., 1993; Aarssen, 1995; Watson, 1995). Thus, a significant feature of plantherbivore interactions is the influence of feeding on plant growth and architecture. Clear differences in herbivore mediated induction of epicormic bud elongation and reductions in flushing stem length were observed (Table 2). Herbivory led to weak apical dominance in M. quinquenervia and resulted in altered plant architecture from increased terminal branches. Similar alterations in plant architecture were observed in Pinus edulis (Engelm.) after attack by the stemboring moth Dioryctria albovitella (Hust.), which resulted in a more prostrate growth pattern from increases in lateral rather than terminal branching (Whitham \& Mopper, 1985). Herbivore-mediated architectural changes in tree form are predicted to lead to disadvantages in competition for light, attraction of pollinators, and seed dispersal (Whitham \& Mopper, 1985; Aarssen, 1995).

An intriguing aspect of $O$. vitiosa feeding is that herbivory bouts lead to temporal extensions in resource availability. In the absence of herbivory, M. quinquenervia trees produce a primary flush of new leaves in late winter (Pratt et al., 2004). The removal of expanding leaves by herbivores, however, induces elongation of auxiliary buds (Table 2). This subsequent aseasonal growth provides additional resources that are exploited by the herbivore, thereby directly increasing carrying capacity of the host. The sustainability of multiple defoliation and refoliation events within a season remains unknown, but is expected to be short lived as stored reserves become limiting. Removal of juvenile leaves by $O$. vitiosa also alters leaf demographic patterns within the tree canopy. Studies conducted prior to the introduction of $O$. vitiosa determined that leaf longevity was $\approx 4$ years (Van et al., 2002). These data suggest that without new leaves to replace their older counter parts, defoliation may be exacerbated through natural senescence. Experimental evidence from other systems, however, has shown that leaf longevity of remaining foliage increases after bouts of partial herbivory (Hopkinson, 1966; Hodgkinson, 1974) and may serve as a possible mechanism for maintaining photosynthetic capacity.

Specialist herbivores play an important role in reducing plant fitness via seed predation (Louda \& Potvin, 1995); however, indirect effects of folivory on plant fitness in natural systems have been less widely studied. Herein, a single herbivory bout of previously undamaged $M$. quinquenervia trees resulted in an $80 \%$ reduction in reproductive structures the following season. An experimental increase in herbivory frequency (two bouts per year) or magnitude ( $100 \%$ simulated herbivory) did not result in additional reductions in fitness. However, under natural conditions in the field, there was an inverse relationship between cumulative herbivory and the probability of $M$. quinquenervia trees reproducing. One explanation for the incongruity among the uniform within season response (Fig. 2) and the multiseason proportional decreases in fitness is the variation in intensity of herbivory. Four years after the introduction of $O$. vitiosa, average defoliation levels at field sites ranged from 75 to $100 \%$ of newly expanding foliage. However, it is unlikely that this level of damage was attained shortly after release of the herbivore or sustained over multiple seasons. In contrast, defoliation levels were more instantaneous and resulted in $95-100 \%$ removal of suitable foliage under caged experiments. These data suggest that a single removal of all new expanding foliage is sufficient to maximise reductions in fitness but levels below this may result in proportionately higher levels of reproduction. Consistent with these data, herbivory in unmanaged systems is typically low, ranging from 5 to $15 \%$ of leaf area (Crawley, 1989; Marquis, 1992). However, as demonstrated in this study, it can not be inferred that leaf feeders have little impact on plant performance (McEvoy, 2002). 
Hoffmann and Moran (1991) found that herbivory by the introduced weevil Trichapion lativentres (Bequin Billecocq) resulted in a $98 \%$ reduction in Sesbania punicea (Cav.) Benth. seed production yet these reductions did not result in concomitant decreases in mature plant densities. Similarly, Noble and Weiss (1989) predicted that seed predation of the shrub Chrysanthemoides monilifera (L.) must reach $95 \%$ of total seed production to halt population growth of the invasive plant. Although herbivory by $O$. vitiosa can clearly reduce fruit and seed production of its host, it remains unclear how these impacts alter $M$. quinquenervia's abundance and invasion potential. The lack of a long-lived soil seedbank ( $\approx 2$ year), however, makes $M$. quinquenervia particularly vulnerable to herbivore-mediated reductions in fitness and delays in reproductive maturation. As canopy held seedbanks continue to diminish over time, reproductive suppression is predicted to have direct, long-term effects on recruitment, invasion potential, and abundance. To test this prediction, future research will examine how herbivores affect stage-specific demographic transitions of $M$. quinquenervia and quantify the effects of herbivory in the context of the entire plant life cycle (Shea \& Kelly, 1998; McEvoy, 2002).

Intentional introductions of natural enemies for the suppression of exotic, invasive plants has been met with criticism due, in part, to difficulties in accurately predicting if herbivores will naturalise and subsequently influence hostplant fitness (Pearson et al., 2000; Pearson \& Callaway, 2003, 2004). A critical step toward improving the predictive accuracy of herbivore-plant interactions includes understanding the ability of plants to tolerate or compensate for loss in biomass. It has previously been suggested that compensation is greatest in nutrient rich aquatic or wetland systems where competition and top-down regulation is minimal (Belsky, 1986, 1987; Maschinski \& Whitham, 1989). In contrast to these predictions, a growing body of literature suggests that invasive, exotic plants growing under favourable conditions fail to compensate for loss in performance due to herbivory by natural enemies introduced as biological control agents. In addition to data presented herein, landscape level population reductions of the aquatic plants Alternanthera phyloxeroides (Mart.) Griseb. (Spencer \& Coulson, 1976) Lythrum salicaria L. (Blossey et al., 2001), Salvinia molesta Mitchell (Room, 1990), and Eichhornia crassipes (Mart.) Solms-Laub. (Center et al., 1999) are attributed to herbivory from a single or small subset of introduced natural enemies. The incongruity among theoretical predictions and empirical evidence from the biological control literature may be due, partially, to the exotic nature of both host and herbivore. While $M$. quinquenervia enjoyed an enemy-free space in its adventive range prior to the introduction of $O$. vitiosa, the same can be said for the current status of the introduced herbivore. In the absence of appreciable top-down regulation, O. vitiosa population densities can far exceed those in its native range. Therefore, compensation predictions developed from natural plant-herbivore interactions may have limited predictive value for recently introduced species.

\section{Acknowledgements}

We thank Cressida Silvers, Steven J. Franks, F. Allen Dray, and two anonymous reviewers for comments on earlier versions of the manuscript. We also thank Sheryl Costello, Carl Belnavis, Jorge Leidi, Stacie Grassano, and Tafana Fiore for assistance with data collection. Mention of trade names or commercial products in this publication is solely for the purpose of providing specific information and does not imply recommendation or endorsement by the U.S. Department of Agriculture. This research was supported, in part, by grants from the South Florida Water Management District, the Florida Department of Environmental Protection Bureau of Invasive Plant Management, and the USDA Areawide Melaleuca Demonstration Program.

\section{References}

Aarssen, L.W. (1995) Hypotheses for the evolution of apical dominance in plants: implications for the interpretation of overcompensation. Oikos, 74, 149-156.

Balciunas, J.K., Burrows, D.W. \& Purcell, M.F. (1994) Field and laboratory host ranges of the Australian weevil, Oxyops vitiosa, a potential biological control agent of the paperbark tree, Melaleuca quinquenervia. Biological Control, 4, 351-360.

Bazely, D.R. \& Jefferies, R.L. (1989) Leaf and shoot demography of an arctic stoloniferous grass, Puccinellia phryganodes, in response to grazing. Journal of Ecology, 77, 811-822.

Bazzaz, F.A. \& Ackerly, D. (1992) Reproductive allocation and reproductive effort in plants. Seeds: the Ecology of Regeneration in Plant Communities (ed. by M. Fenner), pp. 1-26. CAB International, Wallingford, Oxon, U.K.

Belsky, A.J. (1986) Does herbivory benefit plants? A review of the evidence. American Naturalist, 127, 870-892.

Belsky, A.J. (1987) The effects of grazing: confounding ecosystem, community, and organism scales. American Naturalist, 129, 870-892.

Blossey, B., Skinner, L.C. \& Taylor, J. (2001) Impact and management of purple loosestrife (Lythrum salicaria) in North America. Biodiversity and Conservation, 10, 1787-1807.

Boland, D.J., Brooker, M.I.H., Chippendale, G.M., Hall, N., Hyland, B.P.M., Johnston, R.D. et al. (1987) Forest Trees of Australia. Nelson Wadsworth Publishers, Melbourne, Australia.

Burrows, D.W. \& Balciunas, J.K. (1999) Host-range and distribution of Eucerocoris suspectus, a potential biological control agent for paperback tree Melaleuca quinquenervia. Environmental Entomology, 28, 290-299.

Center, T.D., Dray, F.A., Jubinsky, G.P. \& Leslie, A.J. (1999) Waterhyacinth weevils (Neochetina eichhorniae and N. bruchi) inhibit waterhyacinth colony development. Biological Control, $15,39-50$

Center, T.D., Van, T.K., Rayachhetry, M., Buckingham, G.R., Dray, F.A., Wineriter, S. et al. (2000) Field colonization of the melaleuca snout beetle (Oxyops vitiosa) in south Florida. Biological Control, 19, 112-123.

Costello, S.L., Pratt, P.D., Rayamajhi, M.B. \& Center, T.D. (2003) Arthropods associated with above-ground portions of the invasive tree, Melaleuca quinquenervia, in South Florida, U.S.A. Florida Entomologist, 86, 300-322.

Crawley, M.J. (1989) Insect herbivores and plant population dynamics. Annual Review of Entomology, 34, 531-564. 
Doak, D.F. (1992) Lifetime impacts of herbivory for a perennial plant. Ecology, 73, 2086-99.

Dray, F.A. Jr (2003) Ecological genetics of Melaleuca quinquenervia (Myrtaceae): population variation in Florida and its influence on performance of the biological control agent Oxyops vitiosa (Coleoptera: Curculionidae). $\mathrm{PhD}$ dissertation, Florida International University, Miami, Florida.

Dray, F.A. Jr \& Center, T.D. (1996) Reproduction and development of the biocontrol agent Hydrellia pakistanae (Diptera: Ephydridae) on monoecious hydrilla. Biological Control, 7, 275-280.

Ewel, K.C. (1990) Swamps. Ecosystems of Florida (ed. by R. L. Myers and J. J. Ewel), pp. 281-323. University of Central Florida Press, Orlando, Florida.

Goeden, R.D. \& Louda, S.M. (1976) Biotic interference with insects imported for weed control. Annual Review of Entomology, 21, 325-342.

Grabe, D.F. (1970) Tetrazolium testing handbook for agricultural seeds. Contribution No. 29 to the Handbook on Seed Testing. Tetrazolium Testing Committee of the Association of Official Seed Analysts, Lincoln, Nebraska.

Harris, P. (1973) The selection of effective agents for the biological control of weeds. Canadian Entomologist, 105, 1495-1503.

Harris, P. (1988) Environmental impacts of weed-control agents: weed stands have been replaced by diverse plant communities. Bioscience, 38, 542-548.

Harris, P. (1993) Effects, constraints, and the future of weed biocontrol. Agriculture, Ecosystems, and Environment, 46, 289-303.

Hodgkinson, K.C. (1974) Influence of partial defoliation on photosynthesis, photorespiration and transpiration by lucerne leaves of different ages. Australian Journal of Plant Physiology, 1, 561-578.

Hoffmann, J.H. \& Moran, V.C. (1991) Biocontrol of a perennial legume, Sesbania punicea, using a florivorous weevil, Trichapion lativentre: weed population dynamics with a scarcity of seeds. Oecologia, 88, 574-576.

Hofstetter, R.L. (1991) The current status of Melaleuca quinquenervia in southern Florida. Proceedings of the Symposium on Exotic Pest Plants (ed. by T. D. Center, R. F. Doren, R. L. Hofstetter, R. L. Myers and L. D. Whiteaker), pp. 159176. U.S. Department of Interior, National Park Service, Miami, Florida.

Holliday, I. (1989) A Field Guide to Melaleucas. Hamlyn, Port Melbourne, Australia.

Hopkinson, J.M. (1966) Studies on the expansion of the leaf surface. VI. Senescence and the usefulness of old leaves. Journal of Experimental Botany, 17, 762-770.

Julien, M.H. (1989) Biological control of weeds: worldwide trends, rates of success and the future. Biocontrol News and Information, 10, 229-306.

Louda, S.M. \& Potvin, M.A. (1995) Effect of inflorescence-feeding insects on the demography and lifetime fitness of a native plant. Ecology, 76, 229-245.

Maron, J.L. \& Vila, M. (2001) When do herbivores affect plant invasion? Evidence for the natural enemies and biotic resistance hypothesis. Oikos, 95, 361-373.

Marquis, R.J. (1992) A bite is a bite is a bite? Constraints on response to folivory in Piper arieianum. Ecology, 73, 143-152.

Maschinski, J. \& Whitham, T.G. (1989) The continuum of plant responses to herbivory: the influence of plant association, nutrient availability, and timing. American Naturalist, 134, 1-19.

McEvoy, P.B. (2002) Insect-plant interactions on a planet of weeds. Entomologia experimentalis et applicata, 104, 165-179.
McEvoy, P.B., Rudd, N.T., Cox, C.S. \& Huso, M. (1993) Disturbance, competition, and herbivory effects on ragwort Senecio jacobaea populations. Ecological Monographs, 63, 55-75.

McFadyen, R.E.C. (1998) Biological control of weeds. Annual Review of Entomology, 43, 369-393.

Meskimen, G.F. (1962) A silvical study of the melaleuca tree in south Florida. Thesis, University of Florida, Gainesville, Florida.

Noble, I.R. \& Weiss, P.W. (1989) Movement and modeling of buried seed of the invasive perennial Chrysanthemoides monilifera in coastal dunes and biological control. Australian Journal of Ecology, 9, 93-98.

Pearson, D.E. \& Callaway, R.M. (2003) Indirect effects of hostspecific biological control agents. Trends in Ecology and Evolution, 18, 456-461.

Pearson, D.E. \& Callaway, R.M. (2004) Response to Thomas et al.: biocontrol and indirect effects. Trends in Ecology and Evolution, 19, 62-63.

Pearson, D.E., McKelvey, K.S. \& Ruggiero, L.F. (2000) Nontarget effects of an introduced biological control agent on deer mouse ecology. Oecologia, 122, 121-128.

Pratt, P.D., Coombs, E.M. \& Croft, B.A. (2003a) Predation by phytoseiid mites on Tetranychus lintearius (Acari: Tetranychidae), an established weed biological control agent of gorse (Ulex europaeus). Biological Control, 26, 40-47.

Pratt, P.D., Rayamajhi, M.B., Van, T.K. \& Center, T.D. (2004) Modeling the influence of resource availability on population densities of Oxyops vitiosa. Biocontrol Science and Technology, 14, 51-61.

Pratt, P.D., Slone, D.H., Rayamajhi, M.B., Van, T.K. \& Center, T.D. (2003b) Geographic distribution and dispersal rate of Oxyops vitiosa (Coleoptera: Curculionidae), a biological control agent of the invasive tree Melaleuca quinquenervia in south Florida. Environmental Entomology, 32, 397-406.

Purcell, M.F. \& Balciunas, J.K. (1994) Life history and distribution of the Australian weevil Oxyops vitiosa, a potential biological control agent for Melaleuca quinquenervia. Annals of the Entomological Society of America, 87, 867-873.

Ramsey, F.L. \& Schafer, D.W. (2002) The Statistical Sleuth: a Course in Methods of Data Analysis. Duxbury Press, Pacific Grove, California.

Rayachhetry, M.B., Van, T.K. \& Center, T.D. (1998) Regeneration potential of the canopy-help seeds of Melaleuca quinquenervia in south Florida. International Journal of Plant Science, 159, 648-654.

Rayachhetry, M.B., Van, T.K., Center, T.D. \& Elliot, M.L. (2001) Host range of Puccinia psidii, a potential biological control agent of Melaleuca quinquenervia in Florida. Biological Control, 22, 38-45.

Rayamajhi, M.B., Van, T.K., Center, T.D., Goolsby, J.A., Pratt, P.D. \& Racelis, A. (2002) Biological attributes of the canopy-held melaleuca seeds in Australia and Florida, US. Journal of Aquatic Plant Management, 40, 87-91.

Room, P.M. (1990) Ecology of a simple plant-herbivore system: biological control of Salvinia. Trends in Ecology and Evolution, 5, 74-79.

SAS Institute (1990) SAS/STAT User's Guide, 6.12. SAS Institute, Cary, North Carolina.

Shea, K. \& Kelly, D. (1998) Estimating biocontrol agent impact with matrix models: Carduus nutans in New Zealand. Ecological Applications, 8, 824-832.

Smith, R.H. \& Bass, M.H. (1972) Relation of artificial removal to soybean yields. Journal of Economic Ecology, 65, 606-608. 
Spencer, N.R. \& Coulson, J.R. (1976) The biological control of alligatorweed, Alternanthera philoxeroides, in the United States of America. Aquatic Botany, 2, 177-190.

Strauss, S.Y. \& Murch, P. (2004) Towards an understanding of the mechanisms of tolerance: compensating for herbivore damage by enhancing a mutualism. Ecological Entomology, 29, 234-239.

Thomas, P.A. \& Room, P.M. (1985) Towards biological control of Salvinia in Papua New Guinea. Proceedings of the Sixth International Symposium on the Biological Control of Weeds, Vancouver, Canada (ed. by E. S. Delfosse), pp. 567-574. Agriculture Canada, Ottawa, Canada.

Trumble, J.T., Kolodny-Hirsch, D.M. \& Ting, I.P. (1993) Plant compensation for arthropod herbivory. Annual Review of Entomology, 38, 93-119.

Turner, C.E., Center, T.D., Burrows, D.W. \& Buckingham, G.R. (1998) Ecology and management of Melaleuca quinquenervia, an invader of wetlands in Florida, U.S.A. Wetlands Ecology and Management, 5, 165-178.

Underwood, A.J. (1992) Beyond BACI: the detection of environmental impacts on populations in the real, but variable, world. Journal of Experimental Marine Biology and Ecology, 161, 145-178.

Underwood, A.J. (1994) On beyond BACI: sampling designs that might reliably detect environmental disturbances. Ecological Applications, 4, 3-15.
Van, T.K., Rayachhetry, M.B. \& Center, T.D. (2000) Estimating above-ground biomass of Melaleuca quinquenervia in Florida, USA. Journal of Aquatic Plant Management, 38, 62-67.

Van, T.K., Rayachhetry, M.B., Center, T.D. \& Pratt, P.D. (2002) Litter dynamics and phenology of Melaleuca quinquenervia in South Florida. Journal of Aquatic Plant Management, 40, 22-27.

Watson, M.A. (1995) Sexual differences in plant developmental phenology affect plant-herbivore interactions. Trends in Ecology and Evolution, 10, 180-182.

Wheeler, G.S. (2003) Minimal increase in larval and adult performance of the biological control agent Oxyops vitiosa when fed Melaleuca quinquenervia leaves of different nitrogen levels. Biological Control, 26, 109-116.

Wheeler, G.S. \& Center, T.D. (1996) The influence of hydrilla leaf quality on larval growth and development of the biological control agent Hydrellia pakistanae (Diptera: Ephydridae) Biological Control, 7, 1-9.

Whitham, T.G. \& Mopper, S. (1985) Chronic herbivory: impacts on architecture and sex expression of pinyon pine. Science, 228, 1089-1091.

Woodall, S.L. (1982) Seed dispersal in Melaleuca quinquenervia. Florida Scientist, 45, 81-93.

Accepted 2 November 2004 